\title{
THE FULLY FUNCTIONING UNIVERSITY
}




\section{THE FULLY FUNCTIONING UNIVERSITY}

Great Debates in Higher Education is a series of short, accessible books addressing key challenges to and issues in higher education, on a national and international level. These books are research informed but debate driven. They are intended to be relevant to a broad spectrum of researchers, students and administrators in higher education, and are designed to help us unpick and assess the state of higher education systems, policies and social and economic impacts.

\section{Published titles:}

Teaching Excellence in Higher Education: Challenges, Changes and the Teaching Excellence Framework Edited by Amanda French and Matt O'Leary

British Universities in the Brexit Moment: Political, Economic and Cultural Implications

Mike Finn

Sexual Violence on Campus: Power-conscious Approaches to Awareness, Prevention, and Response

Chris Linder

Higher Education, Access and Funding: The UK in International Perspective Edited by Sheila Riddell, Sarah Minty, Elisabet Weedon, and Susan Whittaker 
Evaluating Scholarship and Research Impact: History, Practices, and Policy Development

Jeffrey W. Alstete, Nicholas J. Beutell, and John P. Meyer

Access to Success and Social Mobility through Higher

Education: A Curate's Egg?

Edited by Stuart Billingham

The Marketisation of English Higher Education: A Policy

Analysis of a Risk-based System

Colin McCaig

Refugees in Higher Education: Debate, Discourse and

Practice

Jacqueline Stevenson and Sally Baker

Radicalisation and Counter-radicalisation in Higher

Education

Catherine McGlynn and Shaun McDaid

Cultural Journeys in Higher Education: Student Voices and Narratives

Jan Bamford and Lucy Pollard

Perspectives on Access to Higher Education

Sam Broadhead, Rosemarie Davis and Anthony Hudson

Degendering Leadership in Higher Education

Barret Katuna 
This page intentionally left blank 


\title{
THE FULLY FUNCTIONING UNIVERSITY
}

\author{
BY \\ TOM BOURNER \\ Brighton Business School, UK \\ ASHER ROSPIGLIOSI \\ Brighton Business School, UK
}

AND

LINDA HEATH

Brighton Business School, UK

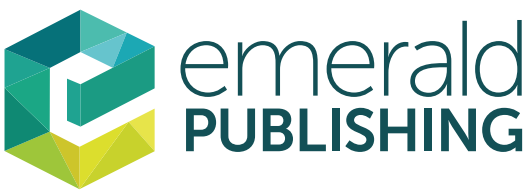

United Kingdom - North America - Japan - India Malaysia - China 
Emerald Publishing Limited

Howard House, Wagon Lane, Bingley BD16 1WA, UK

First edition 2020

Copyright (C) 2020 Tom Bourner, Asher Rospigliosi, Linda Heath. Published under exclusive licence by Emerald Publishing Limited.

Reprints and permissions service

Contact: permissions@emeraldinsight.com

No part of this book may be reproduced, stored in a retrieval system, transmitted in any form or by any means electronic, mechanical, photocopying, recording or otherwise without either the prior written permission of the publisher or a licence permitting restricted copying issued in the UK by The Copyright Licensing Agency and in the USA by The Copyright Clearance Center. No responsibility is accepted for the accuracy of information contained in the text, illustrations or advertisements. The opinions expressed in these chapters are not necessarily those of the Author or the publisher.

British Library Cataloguing in Publication Data

A catalogue record for this book is available from the British Library

ISBN: 978-1-83982-501-9 (Print)

ISBN: 978-1-83982-498-2 (Online)

ISBN: 978-1-83982-500-2 (Epub)

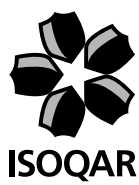

ISOQAR certified Management System, awarded to Emerald for adherence to

Environmental standard 


\section{CONTENTS}

1. Introduction 1

2. The Fully Functioning University 7

3. The Fully Functioning University and its Higher Education

4. The Contribution of the Fully Functioning University to the Advancement of Knowledge

5. The Contribution of the Fully Functioning University to Society

6. Afterword

Appendix 1

Appendix 2

Appendix 3

References

Index 
This page intentionally left blank 


\section{1 \\ INTRODUCTION}

Universities have played a major role in improving the human condition. Arguably, that sentence needs some support as there are those who would challenge the premise that the human condition has improved and also those who would challenge the claim that universities have made a major contribution to any such improvement.

Less than 100 years ago, global life expectancy was under 34 years and now it is more than double that figure at over 70 years (World Bank, 2019a). Two hundred years ago, 85 per cent of the world's population lived in extreme poverty (associated with food insecurity) and that is now down to less than 10 per cent (Bourguignon \& Morrisson, 2002; Deaon, 2013; \& World Bank, 2019b). Either of these astonishing advances is a contender for the title of humankind's greatest achievement. Together, they speak of the escape of the large majority of humankind from the Malthusian trap. And they are sufficient to support the claim for the global improvement in the human condition. It would be possible to fill this chapter, or even a whole book, with further examples of improvement in the human condition globally but hopefully these two astounding achievements will suffice. ${ }^{1}$ 
The role of universities in this improvement has been crucial, because the primary source of this progress has been the advancement of knowledge, particularly the accumulation, dissemination and application of new knowledge, and much of that new knowledge has originated in universities. Moreover, most of the new knowledge produced by researchers over the last 200 years has been the fruit of researchers trained in universities. In other words, universities have contributed directly to the growth of new knowledge on which the massive global improvement in human well-being is based and indirectly by providing the higher education (HE) and research training of most of the researchers in the world, including those working in organisations outside the universities. These two facts should suffice to establish the contribution of universities to the improvement to the human condition over the last two centuries. ${ }^{2}$

This book is about the contribution of the university to the well-being of the world. It is also about the stage of development of the university at this point in the twenty-first century which means that it is about where the university came from and where it is headed. And it is about the tripartite mission of the university, commonly abbreviated as 'research, teaching and service'. ${ }^{3}$ In particular, it is about how the tensions between the three parts of the tripartite mission can be minimised and what can be done to avoid them pulling in different directions. Most specifically, it is about integrating the three parts of the tripartite mission as fully as possible within the university.

So what is this book not about? It is not an account of the scholarly literature on the philosophy of the university and HE. It is not a review of the major issues within the various discourses on universities and HE. And, most definitely, it is not another book lamenting the loss of a 'golden age' of the university.

What is the purpose of the book? Its proximate purpose is to help the university realise as fully as possible the simultaneous achievement of the three parts of the tripartite mission and 
avoid these three goals creating discord, resentments, ineffectiveness and inefficiency. To that extent, it seeks to influence the development of universities in the twenty-first century.

What sort of book is this? It is a positive book; it celebrates what is good about the university and it offers suggestions for its further development. It is a practical sort of book; it contains ideas for how the university can pursue each strand of the tripartite mission in ways that support the other two strands. It is a book with a perspective; it takes the long view from the origins of the university in the high years of the Middle Ages to the emergence of the twenty-first century university. It is a hopeful sort of book; it is written in the confident hope and belief that the remarkable contribution of the university to the advancement of humankind in the past can be sustained and enhanced in the future. And it is a short book.

Why did we write this book? We wrote it because we are that stage in our lives when we are inclined to take the long view. We also wrote it because we believe that universities have become vital to global progress and we are very keen on global progress. Most importantly, we are enthusiasts for universities and want the university to realise its full potential.

What are the book's conclusions? For those who like an 'executive summary' at the start of a book, here is an outline of the core chapters:

Chapter 2: The Fully Functioning University.

This chapter contains an answer to the question, 'What goals have persisted across all the stages of the development of the Western University?' The main conclusion is that the following three goals have been the common threads: (1) the HE of students, (2) the advancement of knowledge and (3) service to the world outside the walls of the university. This may be a surprise to those who associate the development of the tripartite mission with the establishment of the land-grant universities of the USA in the nineteenth century. However, in 
successive stages in the long history of the Western University one or other of these goals has dominated the other two which have been constrained to serve the dominant goal. A university cannot function fully unless it interprets two of its goals in ways that serve the third. The chapter introduces the concepts of a 'post-Humboldtian University' which values each of these goals in its own right, and the 'fully functioning university' as one which expresses all three goals as fully as it can.

Chapter 3: The Fully Functioning University and its Higher Education.

This chapter explores the sort of HE that a fully functioning university would offer. Much of the chapter is spent differentiating three forms of HE that correspond to each of the three parts of the tripartite mission: subject-centred HE, student-centred HE and society-centred HE, respectively. The chapter concludes that the sort of HE offered by a fully functioning university would be one that comprises a subjectcentred part, a student-centred part and a society-centred part. In other words, it would be a university education that prepares students to contribute to the advancement of knowledge in their subject of study (through knowledge creation, dissemination or application), to their own advancement as persons and to the advancement of others beyond the university.

Chapter 4: The Contribution of the Fully functioning University to the Advancement of Knowledge.

The aim of this chapter is to explore the implications of the concept of a 'fully functioning university' for its contribution to the advancement of knowledge. The main question that the chapter seeks to answer is, 'what kinds of research can best support the advancement of knowledge, the HE of students and those beyond the walls of the university, respectively?' The chapter also explores how universities can serve the advancement of knowledge, beyond 'research', that is, in addition to research as that term is commonly understood 
within universities. It concludes with some ideas for how a fully functioning university can contribute to the advancement of knowledge in ways that also contribute to the advancement of students and the world beyond the university.

Chapter 5: The Contribution of the Fully Functioning University to Society.

This chapter is about the contribution of the fully functioning university to the service part of the tripartite mission. Its aim is to identify how the service part of the tripartite mission can best contribute to the tripartite mission in total. The main conclusions are that: (1) there is an identified set of questions that can be used to help enlarge the contribution of third-leg work to the advancement of knowledge, (2) there is another identified set of questions that can be used to help enlarge the contribution of third-leg projects to the HE of students and (3) greater use of project-based thinking within the domain of the third-leg activities can support research-led, and hence evidence-based, practices and outcomes.

The book concludes with an 'afterword' which contains a short reflection on the aims of the book in the light of its conclusions, some implications of these conclusions and some questions surfaced by this enquiry about the direction of universities.

\section{NOTES}

1. It is remarkable how few people are aware of the magnitude of these improvements in human well-being ... including the most educated of people (see Aron, 2019; Rosling Rosling, \& Ronnlund, 2018). According to Rosling et al. (2018) even Nobel Prize winners scored worse than random guesses on a quiz on changes in the well-being of humankind globally. We are curious about whether university Vice-chancellors would fare any better than the Nobel Prize winners on their knowledge of such changes. If you would 
like to test your own knowledge of changes in the human condition against that of the Nobel laureates you can find a copy of the quiz in Appendix 3 to this book.

2. Again, it would be possible to fill this chapter, or even a whole book, with other examples of ways that universities benefit those outside of the walls of universities in both material and nonmaterial ways. See, for example, Shaheen (2011) and BIS (2013).

3. We have much to say about the inadequacy of that common abbreviation in the following chapters. 


\section{2}

\section{THE FULLY FUNCTIONING UNIVERSITY}

This chapter is about what it means to be a fully functioning university in the twenty-first century. This is an important issue because increasing diversification of the range of institutions referred to as universities prompts concern about fragmentation of the university concept. It is important because rapid growth in the number of university students and growth in the number and size of universities raises questions about dilution of the university idea(l). And it is important because rapid structural change within the university sector leads to the question, how much can a university change and still be a university?

The last century has seen an unprecedented increase in the number and size of universities, and that rate of increase has accelerated in the last 30 years. Worldwide, the number of universities has risen as economic development is associated with an increase in the proportion of the population receiving a university education. Continuing world economic growth in real terms means that the global expansion of universities is unabated. Growth in the number of universities has been accompanied by widening in the range of institutions that carry the name 'university'. This widening is exemplified in 
Britain by rebadging the 'polytechnics' as 'universities' in the 1990s. The heterogeneity has been exacerbated by strategic decisions in some institutions to specialise in particular fields and find niche 'markets'. Is such diversification a sign that the notion of a university is breaking up? How far can an institution specialise and still remain a university?

In Britain, recent decades has seen the Age Participation Index for 18 and 19 year olds more than double with ambitions for it to rise further. This has been accompanied by a corresponding rise in both the number and average size of universities. Does growth in the number and size of universities signal increasing relevance of the university concept or is it evident that it is being watered down?

Recent decades have also brought enormous changes to universities. It would not be difficult to make the case that universities have experienced more change in recent decades than in any comparable period in their long history. Here, for example, are a dozen major changes experienced by British universities in recent decades:

1. Rebadging polytechnics as universities in 1992 followed by the addition of about 40 universities since then. ${ }^{1}$

2. Shift from university education for an elite group in society to mass higher education (HE).

3. Increased diversity of the student body.

4. Introduction of fees and government-backed loans for university students with a consequent change towards a perception of the student as a 'customer' of the university.

5. Quantitative assessment of quality with funding being increasingly tied to targets.

6. Development and dominance of league tables.

7. Rise of 'performance' indicators. 